\title{
Marine animal forests as useful indicators of entanglement by marine litter
}

\author{
Galgani François ${ }^{1,{ }^{*}}$, Pham Christopher K. ${ }^{2}$, Claro Françoise ${ }^{3}$, Consoli Pierpaolo ${ }^{4,5}$ \\ 1 IFREMER, LER/PAC, Bastia, Corsica, France \\ 2 IMAR \& Okeanos, Department of Oceanography and Fisheries, University of the Azores, Horta, \\ Portugal \\ ${ }^{3}$ Museum National d'Histoire Naturelle, Paris, France \\ ${ }^{4}$ Institute for Environmental Protection and Research (ISPRA), BIO-CIT, Milazzo, Italy \\ ${ }^{5}$ Stazione Zoologica Anton Dohrn, Napoli, Italy \\ * Corresponding author : François Galgani, email address : francois.Galgani@ifremer.fr
}

\begin{abstract}
:
Entanglement of marine fauna is one of the principal impacts of marine litter, with an incidence that can vary strongly according to regions, the type and the quantity of marine litter. On the seafloor, areas dominated by sessile suspension feeders, such as tropical coral reefs or deep-sea coral and sponge aggregations, have been termed "animal forests" and have a strong potential to monitor the temporal and spatial trends of entanglement by marine litter, especially fishing gears. Several characteristics of these organisms represent advantages while avoiding constraints and bias. Biological constraints and logistical aspects, including tools, are discussed to better define a strategy for supporting long-term evaluation of accumulation and entanglement of marine litter.
\end{abstract}

Keywords : Marine animal forests, Marine litter, Coral, Epibenthic communities, Entanglement, Deep sea 


\section{Introduction}

Entanglement of marine fauna is one of the principal impacts of marine litter. . In a more recent review, entanglement was reported in 418 species from reef systems across eight taxa, also evaluating their major conservation implications (Carvalho-Suza et al., 2018).

Fasting is one of the most frequent consequences of entanglement, as well as, for mobile species, limitations in movementsand thus escaping from predators (Kühn et al. 2015). Entanglement also leads to wounds susceptible to secondary infections and sometimes amputation after constriction (NOAA, 2014). Benthic organisms can also be caught in derelict traps or other litter items on the seafloor. For example, crabs, octopus, fishes and many small invertebrates are commonly captured in lost traps and nets, eventually dying because of starvation (June, 1990; Erzini et al. 2008; Good et al., 2010; Cho 2011).

Although entanglement has been documented in many different types of debris, most records involved fishing gears, especially abandoned, lost, or otherwise discarded fishing gear (ALDFG), with an incidence that can vary strongly according to regions, the type and the quantity of marine litter, especially fishing gears and fishing activities.

Generally, the factors that may influence the probability of an organism being entangled in -or strangled by litter includes the size and structure of the debris, water turbidity, water depth but also behavioural traits (Kühn et al. 2015). For example, the lack of experience of juvenile or immature individuals can make them more vulnerable of being entangled in mesh nets. In young marine mammals, their "playful" and curious behavior has been suggested to increase the incidence of entanglement (Hanni and Pyle, 2000). In addition, ambient noise can hide or distort the echoes produced by ALDFG thus reducing the ability for cetaceans to detect nets by echolocation (Kühn et al., 2015). ALDFG can have an impact on the environment in many 
different ways, including the continuing catch of target species, the catching of non-target species or the entanglement of organisms in litter, and the physical impact of gear on the benthic environment (Gregory, 2009), collectively termed «ghost fishing ». In some cases, ALDFG may represent almost $100 \%$ of total debris, especially in fishing grounds (Pham et al., 2014; Consoli et al., 2018) with monofilament fishing lines perhaps as the most dangerous kind of litter, as they represent a large part of entanglement records (Consoli et al., 2018). Many studies have described entanglement of epibenthic organisms in ALDFG, reaching up to $66 \%$ of the entangled or smothered benthic organisms, in particular for habitat-builders such as corals and sponges (Van den Beld, 2017, Melli et al., 2017).

\section{Monitoring of entanglement}

Although monitoring of litter ingestion in marine organisms has been implemented on solid scientific and technical basis (e.g. Van Franeker et al. 2011), entanglement by marine litter demands an in-depth analysis of the existing data (currently inadequate), and requires substantial work before an optimal strategy can be defined. Tracking the changes in the number or proportion of individuals affected at a given zone is the approach to be used to locate areas at risk and, considering trends, evaluate both the increase and the rate of increase in entanglement. It depends not only on the amount and changes of entangling litter in the environment (exposure) but also the rate at which entangling material moves through the study systems, in relation to both inputs and mitigation measures.

Monitoring entanglement should consider several taxonomical groups (marine mammals, birds, reptiles, fish, and invertebrates) and be organised by ecosystem compartments. Observations can be recorded at the level of beaches (via stranding networks), surface (e.g. during oceanographic campaigns or through observer programmes), and of the seabed, through scuba diving for shallow areas, or submersibles/ROVs/AUVs (Remotely Operated Vehicles/Automated Underwater Vehicles) for deeper waters (RAC-SPA, 2017; Claro et al., 2018). To date, few direct and consistent large scale sampling efforts have been undertaken to understand harm at the population level (RAC-SPA, 2017, Claro et al., 2018). Adequate sampling design is not always easily defined since entanglement consists of isolated events, distributed over wide distribution areas, representing an unknown part of the total number of events and more often without taking into account the total number of cases. It is also important to highlight that the dead entangled animals quickly disappear due to degradation of tissues, sinking or predation. Finally, the item responsible for entanglement is not always identifiable and small items are often not considered. Another in monitoring the frequency of entanglement in marine organisms lies in our capability of distinguishing between bycatch in fishing gear, and entanglement (Kühn et al. 2015). Certain marine organisms, when caught in active fishing gear, can tear it off, attempting to free themselves, or after being released by fishermen who voluntarily cut the gear; in both cases, these animals may continue to move over long distances with bits of gear around their bodies. Moreover, as stated by Ryan (2018), some organisms become entangled in fishing lines after ingestion of baited hooks. 
Overall, there are many difficulties associated with data interpretation. Although stranding networks may present a good way to obtain entanglement data and relevant information at a relatively low cost (Camphuysen, 2008), largescale risk assessments are constrained because of the rarity of stranding, mainly for large organisms. Therefore, the use of stranding can only be useful to particular groups of organisms that can be very locally affected, particularly in areas of intense fishing activity, high density of litter, or high abundance of vulnerable species (Galgani et al., 2013).

In the present stage of development, identifying the constraints inherent to a possible monitoring programme of entanglement is a priority. The constraints, related to the life cycle of the target organisms, integrate several items such as the choice of the species to monitor, their behaviour, thejr development stages, possible migration features and behavioural traits that will influence the probability of encounters between species and litter, a knowledge of the prevalence of entanglement in each species, and a knowledge of pathologies for an accurate diagnosis of the impact after entanglement of individuals.

With respect to the methods used, a certain number of elements are needed to set up a monitoring programme. Data collection scheme, improved standardized protocols, and a knowledge of the seasonal variations in the abundance of litter and target species are critical points that needs to be taken into account when designing a programme. Finally, logistical aspects linked to the cost of the monitoring and the accessibility of samples and data, including opportunistic approaches (e.g. fisheries observer programme, stranding networks or habitat mapping campaigns), are essential aspects that needs to be considered (RAC-SPA, 2017).

\section{Entanglement in marine animal forests}

On the seafloor, areas dominated by sessile suspension feeders (e.g. corals, hydroids and sponges) have been called " animal forests » because they form three-dimensional structures, increasing biodiversity similar to terrestrial forests. We believe that such epibenthic communities (both found in shallow and deep waters) have a strong potential to monitor the temporal and spatial trends of entanglement by marine litter. Several characteristics of these organisms represent advantages while avoiding constraints and bias: Their increased vulnerability to damage due to their slow growth rate (Sheehan et al., 2017) their large distribution in shallow tropical water and in the deep sea, their exposure to marine litter, occurring in both fishing areas,locally, or in remote areas after long distance litter drifting, their immobility allowing a precise location of the entanglement event as opposed to migrating organisms. In addition, the sessile characteristic reduces the risk of misinterpretation due to possible interaction with active fishing gears, especially in MPAs closed to fishing activity, since the species are not moving to them or attracted by any prey already captured in these gears. Subsurface reefs, coral heads and deep-sea coral and sponge aggregations (reefs or gardens), as well as associated organisms are exposed to water circulation and currents, a "way of life" that may expose them more to marine litter, with an abundance of litter significantly higher in the crest 
zone (Figueroa-Pico et al., 2016) and, for the deep sea, higher over rocky bottoms than that on soft substrates (Melli et al., 2017).

Coral bleaching and damage from active fishing activities appears as the most important threats to coral. Evaluating the impacts of marine litter on animal forests started in the 1990s with authors studying damage resulting from fishing activities (mainly netting and lining), revealing it to be the most commonly recorded direct human impact on coral reefs worldwide (Breen, 1990; 1996; Haines, 1997, Bavestrello et al., 1997). The threat posed by both plastic items and fishing gear on benthic communities was further confirmed by many other studies in shallow waters (Asoh et al., 2004; Yoshikawa and Asoh, 2004; Chiappone et al., 2005; Sheehan et al., 2017) and in the deep sea (e.g. Schlining et al., 2013; Pham et al., 2013; Cau et al., 2017), also showing entanglement for reef-associated organisms including crabs and teleost fish (Donohue et al., 2001) but most importantly that the likelihood of diseases increased 20 -fold once a coral is smothered or entangled in plastic (Lamb et al., 2018). In the Marshall Islands, marine debris was shown to act as a significant stressor for coral reefs, causing suffocation, shading, tissue abrasion and mortality of corals, resulting in a significant negative correlation between the level of hard coral cover and coverage by marine debris (Richards and Berger, 2011).

Tropical reefs and deep-sea animal forests act as a sink for litter (Carvalho-Suza et al., 2018). Similarly to any remote and unpopulated areas in the oceans, most of the entangling debris is likely to be derived from local shipping or fishing sources, and distributed by prevailing winds and currents, given that reefs are also subject to sub-surface litter.

In the deep sea, interactions between litter and animal forests have been regularly observed, using submersibles, ROVs and towed camera systems (e.g. Mordecai et al., 2011, Schlining et al. 2013, Pham et al., 2014). Although physical contact of the active fishing gear may not cause visible damage to sessile fauna, the long term effect of lines and ropes constant rasping may eventually lead to pulling, skin abrasion, open wounds, epibiosis and infection. Because of their morphology, gorgonians, habitatforming sponges (e.g. hexactinellidae), hydrocorals and reef-building corals might be more susceptible to this kind of damage (Pham et al., 2013; Oliveira et al., 2015, Angiolillo et al., 2015, Consoli et al., 2018; Rodríguez and Pham, 2017). In contrast, entanglement in derelict fishing gear causes severe damage to corals with evident signs of tissue damage and epibiosis of fouling organisms (Asoh et al. 2004). Yoshikawa and Asoh (2004) suggested that once a coral becomes entangled in a fishing line, there is a high probability of mortality of the colony. During a survey carried out in the central Mediterranean Sea, Consoli et al (2018) observed a significant positive relationship between the number of litter-fauna interactions and the mean litter density, concluding this lindicator could be considered a good tool for monitoring the impact of marine litter on benthic communities.

Recently, a study demonstrated that corals are also exposed to microplastics (Reichert et al., 2018). Cleaning mechanisms such as mucus production, ingestion and egestion were observed, and negative effects (bleaching and necrosis) were documented in various species. Further investigations of the effects of environmentally relevant microplastic concentrations are 
still needed to better understand harm and resilience capacities. We think that regular assessments through opportunistic approaches such as the monitoring of biodiversity in coral reef assemblages by diving, possibly considering kelp forests, or through submersibles / ROV operation in deeper areas are possible. Retrieving information on marine litter that is recorded in underwater visual surveys but also adding marine litter as a routine survey variable in longterm reef monitoring programmes (e.g. Reef Check) are recommended (Carvalho-Suza et al., 2018) and should be implemented on a regular basis. These will support long-term evaluation of accumulation and impacts such as entanglement. For the deep sea, organizing databases that compile photographic records of litter on the seafloor (Chiba et al., 2018), also according with the proposal that websites inviting the public to submit images of entanglement could be a useful tool for documenting the extent of impacts (Ryan, 2018) will also largely contribute to monitoring. The entire approach should give rise to better information in support of the measures to reduce marine litter that will be implemented in the future and permit the definition of a monitoring strategy that is suited to many regional policies such as the United Nations related Action plans on marine litter, especially in tropical areas, or the Marine Strategy Framework Directive for European waters that has included entanglement in the list of impacts to be considered to reach a Good Environmental Status.

\section{References}

Abu-Hilal A., T. Al-Najjar (2009) Marine litter in coral reef areas along the Jordan Gulf of Aqaba, Red Sea. Journal of Environmental Management, 90, 2, 1043-1049, https://doi. org/10. 1016/j. jenvman. 2008. 03. 014

Al-Jufaila S., M. AL-Jabria, A. Baluchia, R. Baldwin, S. Wilson, F. West, A. Matthews (1996) Human Impacts on Coral Reefs in the Sultanate of Oman. Estuarine, Coastal and Shelf Science, 49, 65-74, https://doi. org/10.1016/ S0272-7714(99)80010-9

Angiolillo M., B. diLorenzo, A. Farcomeni, M. Bo, G. Bavestrello, G. Santangelo, A. Cau, V. Mastascusa, A. Cau, F. Sacco, S. Canese (2015) Distribution and assessment of marine debris in the deep Tyrrhenian Sea (NW Mediterranean Sea, Italy), Mar. Pollut. Bull., 92 (2015), pp. 149-159

Asoh K., T. Yoshikawa, R. Kosaki, R. Marschall (2004) . Damage to cauliflower coral by monofilament fishing lines in Hawaii. Conserv. Biol. 18, 1645-1650.

Bavestrello G., C. Cerrano, D. Zanzi, R. Cattaneo-Vietti (1997) Damage by fishing activities to the Gorgonian coral Paramuricea clavata in the Ligurian Sea. Aquat.Conserv. 7, 253-262.

Breen P. (1990) A review of ghost fishing by traps and gillnets. In R. S. Shomura, M. Godfrey (Eds.), Proceedings of the Second International Conference of Marine Debris (571-599). Honolulu, Hawaii: U.S. Department of Commerce, NOAATech Memo, NMFS.

Carvalho-Souza G., M. Llope, S. Moacir, D. Medeiros, M. Rodrigo, C. Sampaio (2018) Marine litter disrupts ecological processes in reef systems. Mar.Poll. Bull., in press.

Cau A., A. Alvito, D. Moccia, S. Canese, A. Pusceddu, C.Rita, M.Angiolillo, M.Follesa (2017). Submarine canyons along the upper Sardinian slope (Central Western Mediterranean) as repositories for derelict fishing gears. Mar. Pollut. Bull. 123(1-2): 357-374. 
Chiappone M., H. Dienes, D. Swanson, S. Miller (2005) Impacts of lost fishing gear on coral reef sessile invertebrates in the Florida Keys National Marine Sanctuary. Biol. Conserv. 121, 221-230.

Chiba S., H. Saito, R. Fletcher, T. Yogi, M. Kayo, S. Miyagi, M. Ogido, K. Fujikura (2018)

Human footprint in the abyss: 30 year records of deep-sea plastic debris, Marine Policy, 2018, , https://doi. org/10. 1016/j. marpol. 2018. 03.022.

Cho D. (2011). Removing derelict fishing gear from the deep seabed of the East Sea. Marine Policy, 35, 610-614.

Camphuysen, C. (2008) Verstrikkingen van zeevogels in zwerfvuil en vistuig, 1970-2007. Sula 21, 88-92.

Claro F., C. Pham, A. Liria Loza, M. Bradai, A. Camedda, O. Chaieb, G.Darmon, A. de Lucia, H. Attia El Hili, E. Kaberi, Y.Kaska, M. Matiddi, C. Monzon-Arguelo, P. Ostiategui, L. Paramio O. Revuelta, C. Silvestri, D. Sozbilen, J. Tòmas, C. Tsangaris, M. Vale, F. Vandeperre, C. Miaud (2018) State of the art: Entanglement with marine debris by biotal. Implementation of the indicator of marine litter on sea turtles and biota in regional seas conventions and MSFD areas. Report of the European project INDICIT (indicit-europa.eu), 54 pages, in press

Consoli P., F. Andaloro, C. Altobelli, P. Battaglia, S. Campagnuolo, S. Canese, L. Castriota, T. Cillari, M. Falautano, C. Peda, P. Perzia, P. Sinopoli, P. Vivona, G. Scotti, V. Esposito, F. Galgani, T. Romeo (2018). Marine litter in an EBSA (Ecologically or Biologically Significant Area) of the central Mediterranean Sea: Abundance, composition, impact on benthic species and basis for monitoring entanglement. Environmental Pollution, 236, 405-415. http://doi. org/10. 1016/j. envpol. 2018. 01. 097

Donohue M., R. Boland, C. Sramek, G. Antonelis (2001) Derelict fishing gear in the Northwestern Hawaiian Islands: diving survey and debris removal in 1999 confirm threat to coral ecosystems. Marine Pollution Bulletin 42, 1301-1312.

Erzini K., L. Bentes, R. Coelho, P. Lino,P. Monteiro,J. Ribeiro (2008). Catches in ghost-fishing octopus and fish traps in the northeastern Atlantic Ocean (Algarve, Portugal). Fishery Bulletin, 106, 321-327.

Figueroa-Pico J., D. Valle, R. -Ruperti, D. Macías-Mayorga (2016) Marine debris: Implications for conservation of rocky reefs in Manabi, Ecuador (Se Pacific Coast). Marine Pollution Bulletin, 119, 5, 7-13 , https://doi. org/10. 1016/j. marpolbul. 2016. 05. 070

Galgani F., G. Hanke, S. Werner, L. Oosterbaan, P. Nilsson, D. Fleet, S. Kinsey, R. Thompson, J. van Franeker, T. Vlachogianni, M. Scoullos, J. Mira Veiga, A. Palatinus, M. Matiddi, T. Maes, S. Korpinen, A. Budziak, H. Leslie, J. Gago and G. Liebezeit (2013) Monitoring Guidance for Marine Litter in European Seas. MSFD GES Technical Subgroup on Marine Litter (TSG-ML). Final REPORT, 120 pages.M.

Good T., J. June, M. Etnier, C. Broadhurst (2010) Derelict fishing nets in Puget Sound and the Northwest Straits: Patterns and threats to marine fauna. Mar. Poll. Bull., 60:39-50.

Gregory B. (2009) Environmental implications of plastic debris in marine settingsentanglement, ingestion, smothering, hangers-on, hitch-hiking and alien invasions. Philos Trans R Soc Lond B Biol Sci. 2009 Jul 27; 364(1526): 2013-2025. doi: 10. 1098/rstb. 2008. 0265

Hanni K., P. Pyle, P. (2000). Entanglement of pinnipeds in synthetic materials at South-East Farallon Island, California, 1976-1998. Marine Pollution Bulletin, 40, 1076-1081

Haines D. (1997) Marine debris on continental islands and sand cays in the Far Northern Section of the Great Barrier Reef Marine Park, Australia. Marine Pollution Bulletin, Volume 34, Issue 4, April 1997, Pages 276-279 https://doi. org/10. 1016/S0025-326X(96)00179-8

June J. (1990). Type, source, and abundance of trawl-caught marine litter off Oregon, in the Eastern Bering Sea, and in Norton Sound in 1988. In: Shomura, R.S., Godfrey, M.L. (Eds.), 
Proceedings of the Second International Conference on Marine Debris, April 2-7, 1989. US Dept. Commerce, NOAA Technical Memo, NMFS-SWF-SC-154, Honolulu, Hawai, pp. 279-301.

Kühn S., E. Bravo Rebolledo, J. Franeker (2015) Deleterious Effects of Litter on Marine Life M. Bergmann, L. Gutow, M. Klages (Eds.), Marine Anthropogenic Litter. Springer International Publishing, Cham (2015), pp. 75-116

Laist D.W. (1997) Impacts of Marine Debris: Entanglement of Marine Life in Marine Debris Including a Comprehensive List of Species with Entanglement and Ingestion Records. In: Coe J.M., Rogers D.B. (eds) Marine Debris. Springer Series on Environmental Management. Springer, New York, NY

Lamb J., B. Willis, A. Fiorenza, C.Couch, R. Howard, D. Rader, J. True, L. Kelly, A. Ahmad, J. Jompa, C. Harvell (2018). Plastic waste associated with disease on coral reefs. Science 359 (6374), 460-462. http://dx.doi.org/10.1126/science.aar3320

Melli V., A. Angiollillo, S. Canese, O. Giovanardi, S. Querin, T. Fortibuoni (2017) The first assessment of marine debris in a Site of Community Importance in the northwestern Adriatic Sea (Mediterranean Sea). Marine Pollution Bulletin, 114, 2, 821-830, https://doi. org/10. 1016/j. marpolbul. 2016. 11. 012

Mordecai G., P. Tyler, D. Masson, V. Huvenne (2011) Litter in submarine canyons off the west coast of Portugal, Deep. -Sea Res. Part II-Top. Stud. Ocean., 58, 2489-2496

NOAA (National Oceanic and Atmospheric Administration Marine Debris Program) (2014) Report on the Entanglement of Marine Species in Marine Debris with an Emphasis on Species in the United States. Silver Spring, MD. 28 pp.

Oliveira F., P. Monteiro, L. Bentes, N. Henriques, R. Aguilar, J. Gonçalves (2015) Marine litter in the upper São Vicente submarine canyon (SW Portugal): Abundance, distribution, composition and fauna interactions. Marine Pollution Bulletin, 97, 1-2, 401-407, https:// doi. org/10. 1016/j. marpolbul. 2015. 05. 060

Pham C., J. Gomes-Pereira, E. Isidro, R. Santos, T. Morato (2013) Abundance of litter on Condor seamount (Azores, Portugal, Northeast Atlantic). Deep-Sea Res. II Top.Stud.

Oceanogr. 98, 204-208.

Pham C., E. Ramirez-Llodra, C. Alt, T. Amaro, M. Bergmann, M. Canals, J. Company, J. Davies, G. Duineveld, F. Galgani, K. Howell, V. Huvenne, E. Isidro, D. Jones, G. Lastras, T. Morato, J. GomesPereira, A. Purser, H. Stewart, I. Tojeira, X. Tubau, D. Van Rooij, P. Tyler (2014) Litter Distribution and Density in European Seas, from the Shelves to Deep Basins, Plos One, 9 (2014), p. e95839

RAC/SPA (Regional Activity Center for Specially Protected Areas Protocol- Barcelona Convention) (2017) Defining the most representative species for IMPA common indicator 18. RAC /SPA, Tunis, 37 pp.

Reichert J., J. Schellenberg, P. Schubert, T. Wilke (2018) Responses of reef building corals to microplastic exposure. Environmental Pollution 237 (2018) 955-960

Richards Z., M. Berger (2011) A quantification of the standing stock of macro-debris in Majuro lagoon and its effect on hard coral communities. Marine. Pollution Bulletin, 62, 8, 16931701, https://doi. org/10. 1016/j. marpolbul. 2011. 06. 003

Rodríguez Y., C. Pham (2017) Marine litter on the seafloor of the Faial-Pico Passage, Azores Archipelago. Marine Pollution Bulletin 116, 448-453. http://dx.doi.org/10.1016/j. marpolbul.2017.01.018.

Ryan P. (2018) Entanglement of birds in plastics and other synthetic materials. Marine Polliution Bulletin, in press. 
Schlining K., S. von Thun, L. Kuhnz, B. Schlining, L. Lundsten, N. J. Stout, L. Chaney, J. Connor (2013) Debris in the deep: Using a 22-year video annotation database to survey marine litter in Monterey Canyon, central California, USA

Sheehan E., A. Rees, D. Bridger, T. Williams, J.M. Hall-Spencer (2017) Strandings of NE Atlantic gorgonians. Biological Conservation. 209:482-487

UNEP (2016) Marine plastic debris and microplastics - Global lessons and research to inspire action and guide policy change. United Nations Environment Programme, Nairobi, 192 p.

Van den Beld B., L. Guillaumont, L. Menot, C. Bayle, S. Arnaud-Haond S, J.F. Bourillet (2017) Marine litter in submarine canyons of the Bay of Biscay . Deep-sea Research, Part II, topical Studies in Oceanography, 145, 142-152. http://doi. org/10. 1016/j. dsr2. 2016. 04. 013

Van Franeker J., C. Blaize, J. Danielsen, K. Fairclough, J. Gollan, N.Guse, P. Hansen, M. Heubeck, J. Jensen, G. Le Guillou, B. Olsen, K. Olsen,J. Pedersen, E. Stienen, D. Turner (2011) Monitoring plastic ingestion by the northern fulmar Fulmarus glacialis in the North Sea. Environ. Pollut. 159, $2609-2615$

Yoshikawa T., K. Asoh (2004) Entanglement of monofilament fishing lines and coral death, Biological Conservation, 17,5, 557-560 